University of Rhode Island

DigitalCommons@URI

The Rhode Island Current Conditions Index

Economics

$12-2019$

\title{
Rhode Island Current Conditions Index - December 2019
}

Leonard Lardaro

URI Department of Economics, lardaro@uri.edu

Follow this and additional works at: https://digitalcommons.uri.edu/ricci

Part of the Econometrics Commons

Terms of Use

All rights reserved under copyright.

\section{Recommended Citation}

Lardaro, Leonard, "Rhode Island Current Conditions Index -- December 2019" (2019). The Rhode Island Current Conditions Index. Paper 193.

https://digitalcommons.uri.edu/ricci/193

This Newsletter is brought to you for free and open access by the Economics at DigitalCommons@URI. It has been accepted for inclusion in The Rhode Island Current Conditions Index by an authorized administrator of DigitalCommons@URI.For more information, please contact digitalcommons-group@uri.edu. 


\title{
CURRENT CONDITIONS
}

\section{LEONARD LARDARO, URI}

\author{
Available Online: http: / www.Ilardaro.com/current.htm \\ Twitter: @ladardo
}

VOL XXVIT

NUMBER 1

DEC 2019

What a way to end the year! Rhode Island's December performance was its best by far for all of 2019. At 92, the December Current Conditions Index value was its highest since June of 2018. And, for the third time in 2019, the Current Conditions Index exceeded its year-earlier value. It should be noted that all three of these "beats" occurred in the second half of the year. Clearly, Rhode Island recovered from the weak patch it experienced during the first half of 2019.

As for individual performances, there was a great deal of strength displayed among individual CCI indicators along with the continuation of several recent uptrends, a most encouraging development. If we focus on the leading economic indicators contained in the CCI, there were several welcome developments. First, and foremost, New Claims for Unemployment Insurance, the most timely measure of layoffs, improved again in December for the seventh time in the last eight months, resuming its longer -term downtrend. Along with this, Employment Service Jobs, a leading indictor of employment, rose strongly again as it has for every month since March. Taken together, these changes suggest a trend toward higher employment accompanied by fewer layoffs in the coming months, necessary elements if Rhode Island is to sustain its recent momentum. Several non-leading indicators turned in noteworthy performances, most notably Rhode Island's star performer for some time now, Retail Sales, which rose at a double-digit rate $(+10.2 \%)$, capping what turned out to be a very strong holiday shopping season.

Two factors in Rhode Island's ongoing performance merit discussion. As everyone but our elected officials know, until very recently, the dramatic declines in Rhode Island's

\section{Indicators - \% Change}

\begin{tabular}{|c|c|}
\hline Government Employment & $0.3 \mathrm{Y}$ \\
\hline US Consumer Sentiment & \begin{tabular}{l|l|l}
1.1 & $Y$ \\
\end{tabular} \\
\hline Single-Unit Permits & \begin{tabular}{l|l}
39.2 & $Y$ \\
\end{tabular} \\
\hline Retail Sales & \begin{tabular}{l|l}
10.2 & $Y$ \\
\end{tabular} \\
\hline Employment Services Jobs & \begin{tabular}{l|l|l}
8.1 & $Y$ \\
\end{tabular} \\
\hline Priv. Serv-Prod Employment & \begin{tabular}{l|l|l}
2.4 & $Y$ \\
\end{tabular} \\
\hline Total Manufacturing Hours & -7.7 \\
\hline Manufacturing Wage & \begin{tabular}{l|l|l}
0.9 & $Y$ \\
\end{tabular} \\
\hline Labor Force & $0.4 \mathrm{Y}$ \\
\hline Benefit Exhaustions & \begin{tabular}{l|l|l|}
-4.4 & $Y$ \\
\end{tabular} \\
\hline New Claims & $\begin{array}{l}-3.7 \mid Y \\
\end{array}$ \\
\hline Unemployment Rate (change) & \begin{tabular}{l|l|l}
-0.5 & $Y$ \\
\end{tabular} \\
\hline
\end{tabular}

Unemployment Rate that occurred had been associated with tepid job growth accompanied by prolonged declines in our state's Labor Force. Since June of 2019, however, our Labor Force and its value relative to our resident population (i.e., our labor force participation rate) have been improving on a monthly basis, the first step, if sustained, to improving yearly values. The same is true for resident employment (the number of employed RI residents) and its value relative to our resident population

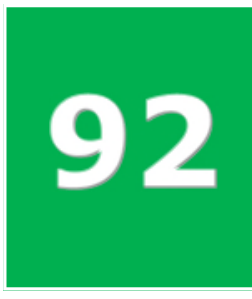

\begin{tabular}{|c|c|c|}
\hline & Jan & Feb \\
\hline 2018 & 75 & $100 \uparrow$ \\
\hline 2019 & 75 & $33 \downarrow$ \\
\hline
\end{tabular}

\begin{tabular}{|c|c|}
\hline Mar & Apr \\
\hline $83 \uparrow$ & $83 \uparrow$ \\
\hline $58 \uparrow$ & 58 \\
\hline
\end{tabular}

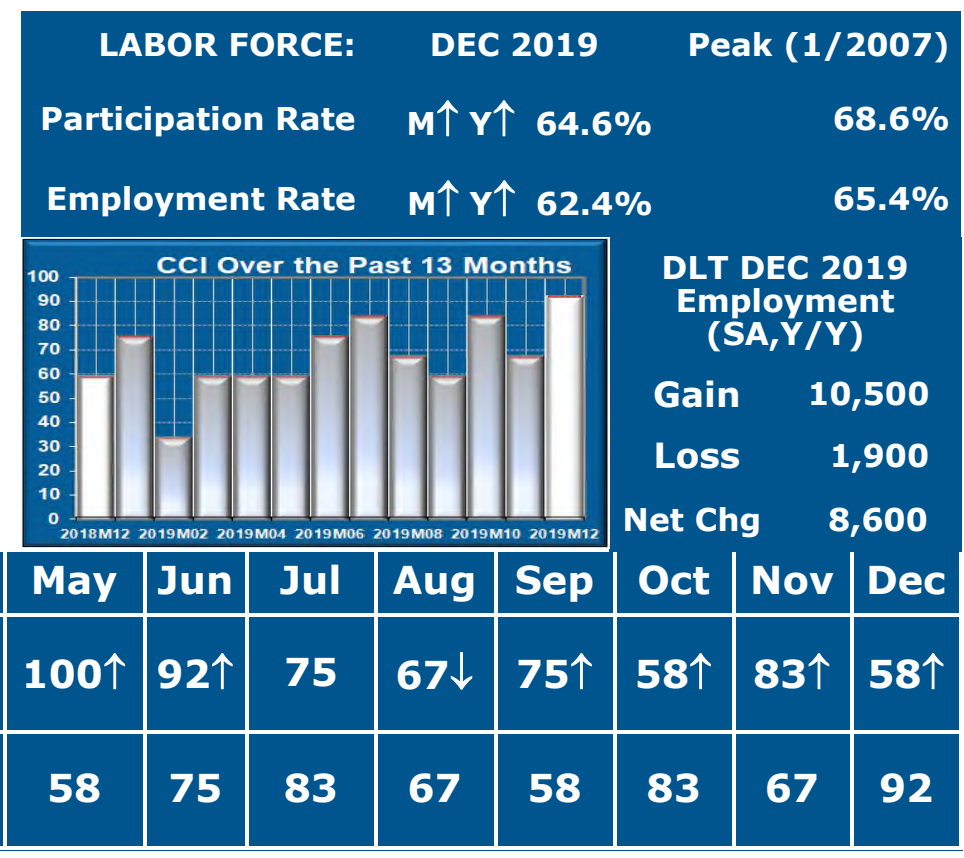

(employment rate). Both trends indicate that our Unemployment Rate is finally behaving as it should, for the "right" reasons. It has been far too long since we have been able to make that claim.

The most pressing question moving forward concerns data rebenchmarking - the upcoming revisions to this year's data, since surges in activity occurred during the months most likely to be revised. I continue to hope that existing values prove to be accurate and the underlying strength we are witnessing at present remains in tact. I am a bit skeptical, though, since there were large downward revisions to the national labor market data.

In spite of all the good news, our weakest area by far continues to be manufacturing. In December, Total Manufacturing Hours, a proxy for manufacturing output, fell for the fifteenth consecutive month $(-7.7 \%)$, as both employment and the workweek both declined yet again. Even the Manufacturing Wage, while improving, grew at its slowest rate in a year $(+0.9 \%)$. US Consumer Sentiment improved this month, but barely $(+1.1 \%)$, its first improvement in the last five months. Single-Unit Permits, which reflect new home construction, surged $(+39.2 \%)$ following an exceptionally easy comp a year ago. Long-term unemployment, based on Benefit Exhaustions, improved in December, but its recent performance remains weak. It is not certain whether this indicator will transition to a meaningful downtrend any time soon. Private Service Producing Employment, which reflects job change focusing on our service sector excluding government, rose by 2.4 percent in December. Its growth has exceeded a two percent rate each month since July. Government Employment increased again in December as it has for eleven of the past twelve months, sustaining a level above 61,000

Finally, our Unemployment Rate remained unchanged at 3.5 percent again in December, which might prove to be its low for this cycle, driven by monthly and yearly increases in our Labor Force. Our Unemployment Rate is now changing for the "right" reasons, no longer driven by a statistical aberration.

Copyright $\odot$ 2018, 2019 Leonard Lardaro, Ph.D. All rights reserved. 